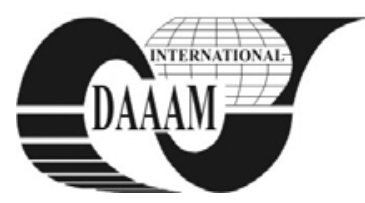

Annals of DAAAM for 2011 \& Proceedings of the 22nd International DAAAM Symposium, Volume 22, No. 1, ISSN 1726-9679 ISBN 978-3-901509-83-4, Editor B. Katalinic, Published by DAAAM International, Vienna, Austria, EU, 2011 Make Harmony between Technology and Nature, and Your Mind will Fly Free as a Bird Annals \& Proceedings of DAAAM International 2011

\title{
MAIN STRUCTURAL FEATURES OF CROATIAN BANKING
}

\author{
GOLEMAC, Z[rinka] \& LONCAR, I[ris]
}

\begin{abstract}
The objective of this paper is to give an insight into the main structural features of the Croatian banking sector: it's classification according to the size of assets, the ownership structure and concentration ratios. The authors find it interesting to analyze the mentioned structural features of the Croatian banking sector, since banking in Republic of Croatia has been transformed from a problem sector into a propulsive sector which managed to achieve relatively stable results despite the oscillations caused by the crisis from 2008/2009. Moreover, Croatian banking sector becomes very compatible with the EU banking system, thanks to its organizational and functional structure, i.e. due to its structural features.
\end{abstract}

Key words: banking, assets, concentrations, ownership structure

\section{INTRODUCTION}

Establishment of financial stability, as well as major loan opportunities and financial products and services on the market, indicate the positive trends in Croatian banking. Liberalisation, privatisation and restructuring in the banking sectors have proven to be key preconditions and promoters of economic stability and development as a whole. From the banking point of view, Croatia is among the most developed transition countries, and on the verge of meeting the European average standards. Namely, from historical point of view, Croatia, having won independence in 1991 and having gained banking sovereignty, has faced several crises in the banking sector.

At the very beginning (until 1993) the crisis was inherited from the previous system, whiles the transition and privatisation procedures contributed in making it worse. During that period it was not possible to accumulate required assets through fiscal policy, consequently the banking system was used as an alternative source of financing national goals (Druzic, 2001). As of 1993, besides the privatisation process and permanent pressure from bank owners (both the state and private owners) on management of the banks regarding investments, the reasons for the crisis can also be found in the chosen fiscal, monetary and exchange rate policy directions.

Within the last decade Croatian banking system successfully weathered all obstacles, it has been completely transformed, and it has become one of the major sectors in Croatian economy. This statement is based also on the research carried out by Lider in co-operation with Poslovna.hr, according to which among 500 top creators of high values in Croatia in 2009 the banks occupy the top position. In terms of value added across sectors, the largest share is held by business banks $-13.3 \%$. Among the 10 top companies there are four banks, and the best company in Croatia in 2009 was a bank with 331 million euro value added. Having taken into consideration the mentioned situation, gaining more knowledge on the banking sector seemed interesting, both through the number, size and Croatian banks ownership structure prism and through analysis of the concentration of assets, loans and deposits.

\section{CROATIAN BANKS PEER GROUPS}

To understand the actual situation in the Croatian banking system we have chosen to analyse the changes that have happened in it during the last decade. Namely, until 2000 there were approximately 60 banks in Croatia, while by the end of the first half of 2010 there were 32 banks and two saving banks in Croatia (Bilten o bankama 21). This number has largely been stable in the past five years. These banks represent the largest group of credit institutions measured by the size of assets (Saunders \& Cornett, 2006). Namely, bank assets (saving banks assets included) stood at HRK $379.5 \mathrm{bn}$ or $98.3 \%$ of the total assets of loan institutions.

\begin{tabular}{|c|r|r|}
\hline $\begin{array}{c}\text { Bank assets } \\
\text { (share in total bank assets) }\end{array}$ & $\begin{array}{r}\text { No. of } \\
\text { banks }\end{array}$ & $\begin{array}{r}\text { Share of } \\
\text { banks (\%) }\end{array}$ \\
\hline \hline Large banks ( $>5 \%$ ) & 6 & 17,7 \\
\hline \hline Medium-sized banks $(>1 \%$ i $<5 \%)$ & 3 & 8,8 \\
\hline \hline Small banks (<1\%) & 25 & 73,5 \\
\hline \hline Total & 34 & 100,0 \\
\hline
\end{tabular}

Tab. 1. Classification of business banks according to the size of assets

According to the relative share in individual bank's assets criteria they are usually divided into large, medium-sized and small banks. The group of large banks consists of the banks with total assets value over $5 \%$ of the total assets of all banks, medium-sized banks include banks with assets $1-5 \%$ of the total assets of all banks, and small banks are the banks with assets below $1 \%$ of the total assets of all banks. The total number of banks at the end of the first half of 2010 included six large, three medium-sized and 25 small banks (Tab. 1).

In spite of their significance with respect to their number within the total number of banks, small banks are close to being irrelevant from the aspect of the share in assets of all banks they controlled only $8.7 \%$ of total assets. On the other side, by the end of the first half of 2010 the smallest group made of the large banks had the largest market share $-82.2 \%$ of total assets of all banks, while the medium-sized banks participated with $9.1 \%$ in the total assets (Fig. 1).

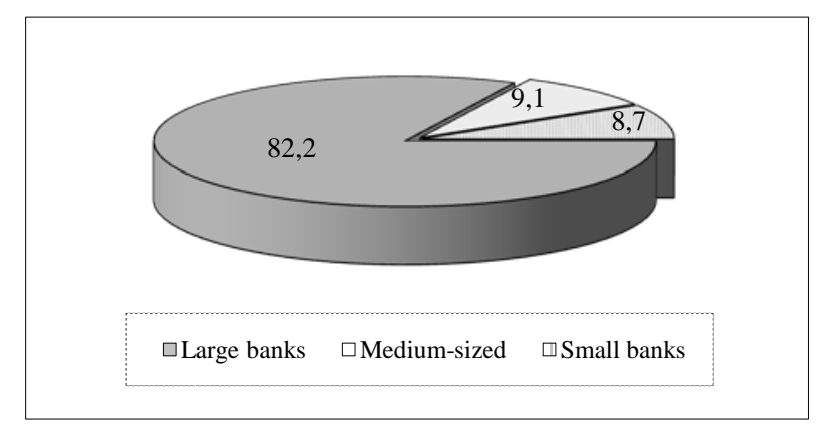

Fig. 1. Asset share in assets of all banks per group 
It is to be pointed out that there has been a reduction in the number of small banks worldwide, consequently, the same is to be expected in Croatian banking sector in future as well.

\section{THE ANALYSIS OF THE CONCENTRATIONS}

Application of concentration ratio, which takes into consideration market shares of the participants, has resulted in the statement that in Croatian banking system the two largest banks dominate the system (Subic, 2009). In 2010 the value of concentration ratio including two most important market participants (CR2) for assets, net loans and received deposits is kept at the level above $40 \%$ (Fig. 2).

The other two concentration ratios, which are being taken into consideration having in mind the specific features of the Croatian banking system, are CR5 i.e. CR10. Concentration ration CR5 in case of assets, as well as net loans and received deposits, is over $75 \%$, while at the same time the concentration ration CR10 shows values above $90 \%$.

Besides the mentioned concentration ratios, when proving concentration of a market the Herfindahl-Hirschman index is used (hereinafter: HHI). To calculate this indicator the square sum of market shares of all participants on the market is taken, consequently, this indicator is taken as a more representative measurement of concentration.

Concentration of assets, net loans and received deposits measured by HHI index is still moderate, since according to the definition a market with HHI between 1000 and 2000 points (1800 is applied in the U.S.) is considered a moderately concentrated market. Having in mind the data from the Croatian banking sector which has been taken into calculation, the asset value index is 1356 points, the net loan value is 1405 and received deposits value is 1412 points.

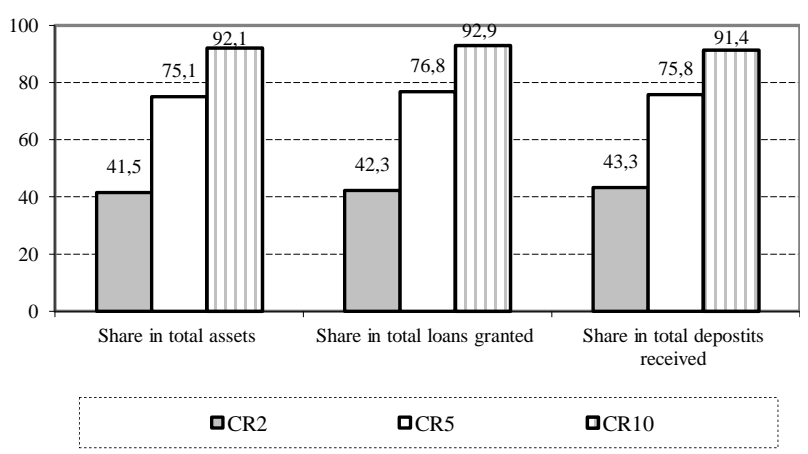

Fig. 2. Shares of largest banks in total assets, loans and deposits

Upon analysis of all indicators shown, it is to be concluded that the Croatian banking sector is characterised by an oligopolic structure. It is polarised into a small number of large banks and large number of small banks.

\section{BANK OWNERSHIP STRUCTURE}

Bank ownership structure at the end of the first half of 2010 was as follows: 19 banks in domestic majority ownership, and 15 banks in foreign majority ownership. However, a more detailed insight in bank shares classified according to the ownership structure in total assets of all banks leads to different conclusions. Namely, this indicates that as much as $90.6 \%$ of total assets of all banks is in foreign majority ownership (Tab. 2).

Having in mind the high percentage of banks in foreign ownership in the total Croatian banking system assets, it is necessary to analyse their role in the consolidation process. In 1994 the first bank established in Croatia was financed by foreign capital. Two years later one more bank was established also by foreign capital, while the remaining three banks from the group of the top five banks, were sold during privatisation process to foreign owners. One of the most important effects from entering of foreign banks in Croatia was that the foreign banks, having entered the ownership structure of one bank, continued to gradually buy shares in ownership structures of other banks. Such action resulted in decrease of the total number of banks (from 60 banks by the end of 1998 onto 34 by mid 2010).

Consequently, all top five banks with respect to assets are in foreign majority ownership. Among the top ten banks there is only one bank in domestic, i.e. state majority ownership. The banks in foreign ownership are mostly banks from Austria, Italy, France, Hungary and San Marino.

\begin{tabular}{|c|r|r|}
\hline Ownership structure & $\begin{array}{r}\text { Number } \\
\text { of banks }\end{array}$ & Share \\
\hline \hline Domestic ownership & 19 & 9,4 \\
\hline \hline Domestic private ownership & 17 & 5,2 \\
\hline Domestic state ownership & 2 & 4,2 \\
\hline \hline Foreign ownership & 15 & 90,6 \\
\hline \hline Total & 34 & 100,0 \\
\hline
\end{tabular}

Tab. 2. Ownership structure of banks and their share in total bank assets

\section{CONCLUSION}

The structural features of the Croatian banking sector nowadays result from strong reforms which have put Croatia, at least in this segment, at the top of the list of the most successful transition countries. Consolidation, privatisations, money transfer reform and strengthening of supervision and control are only some of the specific measures taken to set up a new banking system as the basic sector in Croatian economy.

In spite of the significant decrease of the number of banks in the last decade, the total banking assets have been constantly growing and have concentrated in ownership of 6 large banks. The changes recorded in the banking system were analysed by application of quantitative concentration indicators, and the conclusion has been reached that the banking sector can be defined as a moderately concentrated market. Having in mind that there are 15 banks in foreign majority ownership, and which represent $90.6 \%$ in assets share, it can be concluded that the system works under the strong influence of foreign capital.

It goes without saying that the banking system in the last decade has grown into a new, dynamic and internationally compatible system, contributing strongly to social stability and economic development. However, full integration into the developed European milieu requires additional action with regard to improvement of efficacy, corporate management and increase of competitiveness, but it will also open the possibility to reach higher levels of quality in the banking sector.

\section{REFERENCES}

Druzic, G. (2001). Bankarski sustav. Ekonomski pregled, Vol.52, No.3-4, pp. 293-313, ISSN 0424-7558

Saunders, A. \& Cornett, M.M. (2006). Financijska tržišta i institucije, Masmedia, ISBN 953-157-493-6, Zagreb

Subic, R. (2009). Uloga stranih banaka u okrupnjavanju bankovne industrije. Ekonomski vjesnik, Vol. XI, No. 2, pp. 296-313, ISSN 0353-359X

*** (2010) http://www.liderpress.hr - 500 najvećih stvaratelja nove vrijednosti u Hrvatskoj u 2009, Lider, Accessed on: 2011-04-04

*** (2011) http://www.liderpress.hr - U Hrvatskoj u 11 godina zatvoreno 30 banaka, Lider, Accessed on: 2011-05-11

*** (2011) http://www.hnb.hr - Hrvatska narodna banka, Bilten o bankama 21, Accessed on: 2011-05-15 